\title{
Finitude, temporality and the criticism of religion in Martin Hägglund's This Life: Why Mortality Makes Us Free (2019)
}

\begin{tabular}{|c|c|}
\hline \multicolumn{2}{|c|}{$\begin{array}{l}\text { Authors: } \\
\text { David Biernot }{ }^{1,2} \bullet \\
\text { Christoffel Lombaard }^{2}\end{array}$} \\
\hline \multicolumn{2}{|c|}{ 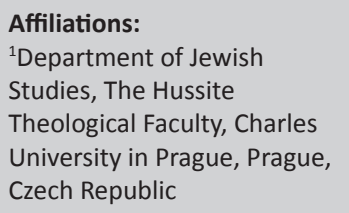 } \\
\hline \multicolumn{2}{|c|}{$\begin{array}{l}{ }^{2} \text { Department of Christian } \\
\text { Spirituality and Missiology, } \\
\text { University of South Africa, } \\
\text { Pretoria, South Africa }\end{array}$} \\
\hline \multicolumn{2}{|c|}{$\begin{array}{l}\text { Corresponding author: } \\
\text { Christoffel Lombaard, } \\
\text { christolombaard@gmail.com }\end{array}$} \\
\hline \multicolumn{2}{|c|}{$\begin{array}{l}\text { Dates: } \\
\text { Received: } 30 \text { Apr. } 2020 \\
\text { Accepted: } 12 \text { Aug. } 2020 \\
\text { Published: } 04 \text { Nov. } 2020\end{array}$} \\
\hline \multicolumn{2}{|c|}{$\begin{array}{l}\text { How to cite this article: } \\
\text { Biernot, D. \& Lombaard, C., } \\
\text { 2020, 'Finitude, temporality } \\
\text { and the criticism of religion in } \\
\text { Martin Hägglund's This Life: } \\
\text { Why Mortality Makes Us Free } \\
\text { (2019)', HTS Teologiese } \\
\text { Studies/Theological Studies } \\
76(2), \text { a6072. https://doi. } \\
\text { org/10.4102/hts.v76i2.6072 }\end{array}$} \\
\hline \multicolumn{2}{|c|}{$\begin{array}{l}\text { Copyright: } \\
\text { (c) 2020. The Authors. } \\
\text { Licensee: AOSIS. This } \\
\text { is licensed under the } \\
\text { Creative Commons } \\
\text { Attribution License. }\end{array}$} \\
\hline \multicolumn{2}{|l|}{ Read online: } \\
\hline 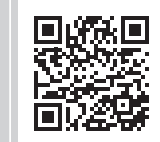 & $\begin{array}{l}\text { Scan this QR } \\
\text { code with your } \\
\text { smart phone or } \\
\text { mobile device } \\
\text { to read online. }\end{array}$ \\
\hline
\end{tabular}

Based on two presentations during a February 2020 South African academic visit at the University of Pretoria and the University of Johannesburg, in this contribution, the authors of this article engage with one of the bestselling recent volumes in philosophy, Martin Hägglund's This Life: Why Mortality Makes Us Free (here, the 2020 edition; initial publication date, 2019). In this book, Hägglund propagates ideas akin to those promoted within secular humanism. Whilst on the one hand this article elaborates the shortcomings of Hägglund's criticism of religion, on the other hand it also strives for an empathetic reading of his secular humanist philosophy. The authors place this conversation within the post-secular religio-cultural climate currently rising internationally, along with some further contextualising remarks. The most important part of this article is the last section ('Pitting some theological voices...') in which the authors engage Hägglund's main arguments theologically, which elaborate on the finitude of human life all the whilst denying it a prospect of immortality. The debate in this section procceeds along the lines of religious thought of Emmanuel Falque, Ebenhard Jüngel and Dewi Zephania Phillips, with a view to reconcile the radical awareness of finitude and temporality of human life, characteristic for modern discourse(s), with the religious language practices sustaining belief in eternal life.

Contribution: This article engages with how Martin Hägglund's This Life: Why Mortality Makes Us Free does not fairly convey aspects of the sense of secularism, and can additionally on the senses of finitude and temporality be improved by insights from Emmanuel Falque, Ebenhard Jüngel and Dewi Zephania Phillips.

Keywords: New atheism; Secular humanism; Martin Hägglund's This Life (2019); Martin Hägglund; The temporality of life; Immortality.

\section{Introduction: Hägglund's book culturally placed}

Although the contribution here will focus primarily on a cluster of selected issues in Martin Hägglund's recent book This Life: Why Mortality Makes Us Free (2019, initially published in the United States of America as This Life: Secular Faith and Spiritual Freedom, which ranked amongst the bestselling titles in contemporary philosophy in 2019), ${ }^{1}$ a few words should be said about the author and the background against which his book can be contextualised. Hägglund, born in 1976, hails from Sweden and is currently at Yale University in New Haven, Connecticut, as Professor of Comparative Literature and Humanities. Before publishing the title presently under discussion, Hägglund prepared the way for this volume with two prior publications: Radical Atheism: Derrida and the Time of Life (2008) and Dying for Time: Proust, Woolf, Nabokov (2012). Although all three books seem to deal strictly with the problems of temporality and finitude as reflected in various philosophical and literary sources, their ideational scope reaches well beyond philosophy, indirectly reflecting an array of contemporary social phenomena. One of them is elements of post-secularism, a notion that is currently so much in vogue that its use even becomes at times perplexing. 1.Whilst it may be unsuitable to refer to academic writings as 'bestsellers', these two titles penned by Hägglund have undoubtedly
garnered significant public attention from readers looking for fresh insights in spirituality in the so-called post-Christian age. This
attention has been widely reflected by columnists in American, British and continental European newspapers in the past year. Cf. for
example Burkeman (2019) and Rashid (2020). Reference to Hägglund hence also appears in newspaper articles dealing with the looming environmental crisis and the resultant demand for taking political action - Diez (2019).

Note: Special Collection entitled Christianity as Change Agent in the 4th Industrial Revolution World, sub-edited by Erna Oliver (UNISA) 
Generally, post-secularism is associated with the demise of the secularisation thesis ${ }^{2}$ propagated in the 19th and 20th centuries, and hence acknowledges the renewed, if slowgoing and often unperceived, resurgence of religion in both private and public spheres of Westernised democracies over the past three decades. Signs of such a resurgence, not to be confused with a revival in the evangelical movement sense or with a one-dimensional return to only earlier expressions of faith, are to be found far and wide. Some of these aspects have been traced in our prior joint research (Biernot \& Lombaard 2017:1-12). ${ }^{3}$

In addition, even in a country such as Australia, with its popular self-understanding of its public life as being religion-free, a protective Religious Freedom Bill has recently been proposed, which has however been punned by its opponents as a 'Religious Discrimination Bill' in that it would, according to its critics, have a strongly divisive and potentially harmful effect in public life (Karp 2019). Not only will the passing of such a bill open the door to discrimination, it is argued, but the bill may also legitimise forms of social behaviour compromising good manners in public. For example, a teacher would be allowed to tell a student with a disability that her condition is a trial brought upon her by God. As a further illustration of the feared effects, a person belonging to a certain religious group may be told by a member of another religious community that he is destined for eternal damnation. A similar legislative action has also been taken by Donald Trump's administration (Stern 2019). This kind of negative reaction to religionpositive developments in the sphere of law is not unknown where such measures have in other contexts been taken. When for instance the South African Charter of Religious Rights and Freedoms (2009) had been accepted by almost all religious institutions in South Africa (cf. Benson 2011:125134; more generally, Benson 2012), the Charter too had been accused of a similar search for privilege (Rousseau 2012); this, as competing senses of what constitutes a liberal democracy, plays out in public debate (cf. Benson \& Lombaard 2019).

2.For the meaning of this notion see, for example, Taylor 2007:431-432: 'A difficulty in this whole discussion is that there is some unclarity as to what exactly the "secularization" thesis amounts to. There are in fact, thinner and wider versions. What I'm calling the mainstream secularization thesis might be likened to a threeWhat I'm calling the mainstream secularization the storey dwelling. The ground floor represents the factual claim that religious belief and practice have declined, and that "the scope and influence of religious institutions" is now less than in the past. The basement contains some claims about how to explain these changes. In Bruce's case, the account is in terms of social fragmentation (including what is often called "differentiation"), the disappearance of community (and the growth of bureaucracy), and increasing rationalization. But this doesn't exhaust the richest versions. These add a storey above the ground the age of mobilization floor, about the place of religion today. Where has the whole movement left us? What is the predicament, what are the vulnerabilities and strengths of religion and unbelief today? Here we are in the domain that I have designated secularity, and of course, it is the answers in this domain, the upper storey, that interest most people, non-scholars, but not only them. Now much of the confusion about whether or not one agrees with "secularization" comes from the imprecision about how much of the building we're concerned with. If it's just the ground floor we're talking about, then there is wide concerned with. It just the ground floor we the talking about, then there is wide agreement on the general drift, even though there be some cavilling at the details. Bruce often ropes in a broad church of scholars who allegedly agree on secularization, including, for instance, Martin and Berger. If this claim holds, it only extends to the ground floor. Once we get to the basement and the upper storey,
divergences are evident'.

3.Cf. also Zeidan (2003), eds. Molendjik, Beamont and Jedan (2012), Nynäs, Lassanda and Utriainen (2012) and Okeja (2019)
Such a debate on this matter, of how religion could be placed within, on the margins of or fully outside the most noticeable spheres of Western/ised or liberal democracies, is not unexpected. It would be surprising if the matter had not been opened for discussion, and had that been the case, that would be the firmest indication that religion had indeed suffered a quiet death (cf. Taylor 2007). On this matter, of the place and role of religion within society, there has however never been a unanimity. It is clear that the postsecular age has not brought Western society unequivocally back to the pre-modern civitas dei, taken by secularisation and turned into civitas terrena. Instead of that, Western/ised societies have remained divided, being both 'with God' and 'without God' in various contexts of the public arena and in private life.

Nigel Leaves, a religious studies scholar in Australia, has hence painted the post-secular landscape of the 2000s and 2010s in grim colours, conjuring up a picture of a disrupted and polarised society consisting of social segments living in isolated ideological ghettos, each one being catered to by their own media outlets and pursuing their own ideological agendas (Leaves 2011:1196-1206). The recurrent incursion of conservative, fundamentalist Christianity into the public sphere, most visibly so in the United States of America, has been met with the ardent opposition of the so-called New Atheism movement, stoked by its 'Four Riders' - its most popular proponents: Dawkins (2006), Dennett (2006), Hitchens (2007) and Harris (2014), with a large community of natural scientists and others filing in behind them. In 2006, the Salk Institute for Biological Studies in California organised a symposium entitled 'Beyond Belief, Science, Religion, and Survival', which illustrates this contestation. The conference was held in a war-mongering tone, questioning the place of religion in both the private and public spheres, and asking whether scientists should not be bolder in their refusal of religion.

When religion is done away with, what is supposed to be put in its place? Can humans act in an ethically sustainable way without having to rely on the belief in a supranatural god (Leaves 2011:1189)? On the other hand, Van Huysteen (2006) had contemporaneously argued from a multidisciplinary approach in favour of the evolutionary necessity of religiosity as part of the constitutive apparatuses (along with e.g. language, motor abilities, conceptual skills, etc.) required for the survival of Homo sapiens throughout its history, whilst at roughly the same time the new academic discipline of spirituality studies was coming into its own (Kourie 2009:148-173). Religio-cultural deliberations, both in explicit argumentation and in implicit contestations, remain to a vital extent unremitting.

Almost needless to say, therefore, our decade continues to see a rise in various secular, anti-religious (cf. however Vanhoutte 2020) initiatives keen to stem the influence of religion, offering an alternative narrative and framework for, for instance, social bonding, in particular in Englishspeaking countries. As an example, in 2019, the British 
Humanist Association, the most pre-eminent non-religious organisation in the United Kingdom, had 85000 registered members and fans (Humanist UK 2019). Basing himself on his in-depth field study, Matthew Engelke points out that in spite of the resolution on the part of many humanists to act as 'enlightened moderns', fully committed to a non-religious lifestyle and a naturalistic view of the universe, secular humanism has not been able to effectively cut its ties with what Engelke vaguely referred to as 'Christian culture' (Engelke 2014:296). We cannot, it seems, look away from the fact that there are individuals and whole groups within this broad community who insist on keeping the continuity with Christianity and Judaism, especially when it comes to the historical, social and personal confessional legacies, in the case of the United Kingdom, in particular of Anglicanism (cf. Leaves 2005: 96-102). Also, in the United Kingdom there is a high demand for non-church alternative rites of passage, that is, secular humanist name-giving ceremonies, weddings or funerals. In South Africa, a parallel movement, the New Reformation Network ('Nuwe Hervorming Netwerk'; cf. Muller 2002) was similarly given to weekly, most particularly, Sunday gatherings as a form of strengthening socially their views. The a-, non- and anti-religious expressions of Western/ised culture seems to readopt religious rites and expressions to mark the aspects of the human experience.

As additional examples, 2 years ago, the National Health System in the United Kingdom appointed the first secular humanist chaplain, a decision hailed by the Guardian columnist Andrew Brown as 'a welcome sign of the United Kingdom's shifting spirituality' (Brown 2018). On the other hand, Engelke (2014:297) remains aware of the common perception of secular humanism that it is Protestantism in all but name, as he points out that this movement is deeply committed to a break with Christian, Jewish or other religious narratives (cf. however Lombaard 2018:1-7, relating a diversity of such expressions). By 'religion', secular humanists mean above all a cluster of beliefs revolving around the idea of a supranatural god. By the same logic, however, the label of 'secular' is applied to anything that counters these beliefs (cf. Vanhoutte 2020). Whilst invoking recent data provided by the study of atheism and non-theistic beliefs, Mills (2016:168) argues that there are up to 750 million people worldwide who have dropped the word 'god' altogether out of their semiotic system and lexicon of meanings. It is clear from such instances that secular humanism is a phenomenon that is a part of the unfolding of a larger and increasingly ambiguous post-secular development in our time, paradoxically marked by both the resurgence of religion and the loss of faith in supranatural realm. James A. Beckford goes even further, doubting that the notion of post-secularism has any legitimate footing in contemporary social reality. He 'demystifies' this concept as a scholarly construction that is still in the process of developing. Beckford also treats the idea of the secular coming to an end as difficult to accept (Beckford 2012:12). Here too, the resolution of contested views remains far off.

\section{Hägglund's book philosophically placed}

Given the latter trend of contestation, Hägglund's book undoubtedly shares much with the ideology of secular humanism, without however openly subscribing to it. The book occasionally reads as a sort of manifesto, almost, which to an educated guess reflects indirectly the ongoing cultural war between the conservative 'religious right' and progressive 'secular left' within Hägglund's adopted country, the United States of America. Hägglund's address seems to be primarily to American readers, rather than to those from Europe and other continents, despite the second edition being published (under the altered subtitle indicated here in the opening paragraph) in the United Kingdom. In its combining of issues pertaining to spirituality, culture and politics, this volume could probably be ranked on a par with one of the most vocal of American apologetes of 'secularism', Phillip Zuckermann (Zuckermann 2014).

From a philosophically analytical perspective, a significant part of Hägglund's book reads almost as a veiled elaboration on Heidegger's concept of authenticity. According to Heidegger (1962:229-235), human beings in their Dasein have in their worldliness a penchant to fall into everydayness, understood as the common world of experience that is most readily at hand - a way of being Heidegger branded as the impersonal 'Das Mann' ('they', in English translations). Everydayness degrades the best possibilities of Dasein to issues based on common understanding that prefigure our possibilities: in the goods we buy or ideas and clichés we subscribe to, Dasein becomes reduced to an inauthentic way of being. We may be awakened from the tranquility of everydayness by Angst (a heritage from Kierkegaard; cf. Kenneth 2016:15-26), when the totality of our entanglement with the world falls away. In Angst, Dasein is thrown back upon that about which it is: its authentic potentiality-beingin-the-world. It is Dasein in its finitude that we are anxious about. The authenticity of Dasein demands a clear acceptance of the finitude of Dasein, as the totality of Dasein reveals itself only in the being-towards-death (Heidegger 1962:229-235): as long as I am alive, I therefore continue to take a stand on what it means to be. My identity is still an open project of incessant revisions and reinterpretations. By taking this or that option, I can however exercise my existential freedom, determining what the course of my life will be from now on. I also possess the interpretative opportunity to reshape and redefine the meaning of what my life has been about until now. Until my death, my Dasein will be in 'ahead-of-itself' mode, which is concomitant with Sorge - 'care' as the basic state of Dasein (Heidegger 1962:370-380). Death moves us to show concern about our lives, although Heidegger does not rule out ignorance of death on the part on many, which makes them flee from death. There are many ways of maintaining oneself in this being; however, some of them are not authentic (Heidegger 1962:476-480): seeing itself slipping away into non-being, Dasein cannot bear its temporality and flees in the face of death. These analytics of Dasein by Heidegger seem 
to echo throughout Hägglund's discourse; this impression can hardly be ignored from a philosophically informed perspective. Hägglund's position is nevertheless specific, by viewing the religious way of maintaining oneself in the world (i.e. in holding supranatural beliefs) as a particular example of the fallenness of Dasein into inauthenticity.

However, it is to a more explicit extent Augustine's (1972) Confessions, rather than Heidegger's Being and Time, that Hägglund takes recourse to in his reflection on the temporality and finitude of human life. Hägglund's attention is namely attracted to the passages in which Augustine laments the impossibility of reposing in a timeless presence. The moments of our lives pass away quickly and no one is able to follow them with their bodily senses. Nor can anyone grasp these moments tightly, even when they are present (Hägglund 2019:81-89). The movement of time is unforgiving, as it makes everything disappear, and we can deal with this movement of time only from the perspectives of memory and anticipation. Even our perception, as Hägglund adds, is not sheer receptivity, but rather activity retaining what happens and relating to what may come. Put in Heiddegerian idiom, we exist as three temporal dimensions or 'ecstases' at once: being ahead of ourselves in the future, drawing on our past, whilst being concerned with the present, which together conditions our being. So to speak, we extended outwards in these temporal ecstasies so that we are never contained in a 'punctual' here and now (Heidegger 1962:377-380; Hoffmann 1993:208-210). For Augustine, this distention of time is a mark of unhappiness and the seal of the fallen state of humanity.

In his reading of the Confessions, Hägglund attempts to portray Augustine as a man of conflicted loyalties. On the one hand, Augustine is fascinated by the extases of temporality, revelling in the power of memory that creates an 'interior place', which allows him to recall whom he had been or reminds him of anything hidden away or neglected (Confessions X-XI). Hägglund labels this kind of amazement on the part of Augustine as 'secular' in its very nature (Hägglund 2019:87-88). Augustine's very finite being triggers his (Augustine's) interest to explore the recesses of the interiority ('soul') of a mortal being. Nevertheless, this curiosity cannot prevent Augustine's 'religious' selfperception to hold sway. The temporal distention of his life is for Augustine not his true life. He longs for surpassing the temporal and spatial framework of his interior life, to have a share in the eternal framework, in the presence of God: 'I will transcend even this my power, which is called memory. I will rise beyond it to move to you' (Confessions XIII:17). Hägglund regards Augustine's religious denunciation of the 'glue of care' (curae glutino), which binds us to sensual objects, as a failure and as disloyalty to one's finitude, that is the vulnerability of life and being are exposed to an abrupt end (Augustine 2003:8; Hägglund 2019:90).

Hägglund treats other religious (Christian) writers in much the same way: as personalities suffering from the quandary of conflicted loyalties, torn between their love for the eternal
God and for their loved ones in this world. Some instances are presented. In 1542, Martin Luther wrote a letter to his friend Jonas Justus in which he confessed his failure to get over the unbearable grief following the death of his daughter Magdalena, on whom he had doted. Luther says that whilst he and his wife should rejoice over their daughter's escaping of the power of the flesh, in reality there is no remedy to their pain, and even the thought of Christ's redemptory death cannot bring them relief (Hägglund 2019:88-89). Hägglund dwells much longer on C.S. Lewis' analysis of his own grieving after the passing away of his wife (Joy Davidman), which he described in the book entitled A Grief Observed (Lewis 2001). Hägglund highlights Lewis' desire to bring back the days he spent with his wife in physical intimacy, and his difficulty to conjure up a picture of both of them as 'two unimaginable, supercosmic, eternal somethings' (Hägglund 2019:62-63; Lewis 2001:24). Despite his wish for the temporal continuity of their relationship, Lewis rejects the popular vision of afterlife as a happy reunion of the people who have loved each other as unbiblical. He concludes the account of the last moments at his wife's deathbed with a quote from Dante's Paradise: 'Pois si tornò all eterna fontana' - 'Then she turned towards the eternal Fountain' (Lewis 2001:76). Not unlike Dante's Beatrice, Davidman turned away in her dying from Lewis to contemplate the radiance of God (Hägglund 2019:64-65).

How are these instances cast by Hägglund?

\section{Hägglund's afterlife and life}

Hägglund associates religion not only with belief in a supernatural god, but above all with belief in the completion of human life in eternity, understood either as timeless afterlife or as endless continuum. Both variations are for him meaningless (Hägglund 2019:46-47). Acts performed in an endless continuum would lack the urgency, uniqueness and irreversibility conditioned by the finitude of human life. Against the stasis or continuum of eternity, Hägglund sets the exhaustible energeia of the finite life, characterised by vitality as well as vulnerability. He understands all living beings as purposive self-maintaining entities. Even in human beings, it is in the first place their purposive activity expressed in experiencing and doing (called 'spiritual selfmaintenance' by Hägglund) that makes them human, rather than the reflection of who they are (Hägglund 2019:173188). This purposiveness is strictly this-wordly, temporal and finite. There is no higher purpose or completion beyond the world.

Hägglund employs to this end the notion of 'secular faith', which strikes the note of much of the first part of the book. Secular faith may find, according to Hägglund, its expression in the commitment to one's life, to the life of other people or to a project. There are hence no metaphysical foundations underpinning one's commitments. The worthiness of life cannot be demonstrated rationally and must be taken on 'faith' only. Faith is therefore the basis for all forms of care, taking the risk of failure and loss (Hägglund 2019:45-46). 
Hägglund's quasi-religious language of 'having faith in our lives' echoes to some extent Don Cupitt's study of the transformation of language practices in the United Kingdom amongst religiously estranged people over the past few decades, in which many God-idioms have been gradually replaced by Life-idioms. 'Life' has in other words become the most popular totalising term retaining some religious significance. These idioms have been turned into metaphors that personalise Life. 'Life' may in this manner be attributed dispositions and may be spoken of as something (somebody) we have dealings with. Phrases such as 'having faith in life', 'tempting life' and 'wrestling with life' are the most common (Cupitt 2012:85-87).

Hägglund's discourse, stressing our commitments to the this-wordly life and taking care of this life in any possible way, has strong ethical undertones, although with an 'anti-religious' edge, - which is quite typical of the rhetoric of secular humanism. He levels his criticism against 'religious faith' in particular for downplaying the irreplaceability of a lost life. He, therefore, censures Barack Obama for his speech at the memorial service for children killed in a mass shooting in Newtown, Connecticut, in 2012. Obama introduced his address with a quote from Matthew 19:14: 'Let the little children come to me, and do not hinder them. For such belongs to the Kingdom of Heaven'. Hägglund finds it entirely inappropriate, as that text may insinuate that the slaying of the children in the Newtown school was not an ultimate loss and tragedy. The victims were thus transferred to a higher existence in the Kingdom of God. This is a 'religious consolation', Hägglund (2019:65) states.

A 'secular consolation' has however no ambition to redeem mortality; death remains hopeless. Therefore, a secular consolation rather moves one to take social action, motivating the public to prevent similar tragedies (Hägglund 2019: 66-68). Hägglund's portrayal of 'religious faith' in such a manner is undoubtedly tailored so as to support the arguments laid down in the rest of his book. There is therefore in this matter a sense of coherence in the build-up of his argumentation. His accusation levelled against religious people as 'quietists' and hence as less motivated to take socially responsible action can be viably illustrated at the hand of a recent $\mathrm{HBO}$ documentary Outside the Bubble: On the Road with Alexandra Pelosi (2018), on the mood in the mostly rural, evangelical Trump-voting regions of the United States of America. On her journey, Pelosi interviews the survivors of the 2017 mass shooting in the First Baptist Church in Sutherland Springs, Texas. Some of the interlocutors who had lost their loved ones in this carnage found their peace in belief that their deceased relatives are in a better place now, dodging in this way the burning political and social implications of the tragedy that had turned their lives upside down.

However, this argument by Hägglund is undoubtedly false, across the board. In his reductive reading of the religious frame of mind, Hägglund disregards its social awareness, stimulated across the centuries by the biblical ideas of justice and solidarity. The late 19th-century Social Gospel movement can serve as an excellent example of religious social engagement. The proponents of the Social Gospel movement, amongst them Walter Rauschenbusch (the grandfather of the influential American neo-pragmatist philosopher Richard Rorty), were post-millenialists who believed that the Second Coming of Jesus would not happen until social evils are eradicated by human social action. As social reformists, they attempted to stave off the growth of apocalyptic tendencies in American religion seeing the world as an evil place coming to a near end (Evans 2017:21). Many instances of Liberation Theology, Black Theology, African Theology, Feminist Theology and Ecological Theology can be employed further to illustrate the strongly this-worldly interest of Christianity over the past century. In this respect, Hägglund's juxtaposing of religious and secular faith lacks historical profundity. Up to very recent times and even then only in certain circles, the word 'secular' connotes the action of the faithful in the world, rather than the departure of the world from religion (cf. Vanhoutte 2020). Charles Taylor described the process of uprooting from its original context and modernisation of this notion in his famous book Secular Age. ${ }^{4}$

Hägglund's selection of 'religious' (mostly Christian) authors to critique seems correspondingly biased. These writings serve for him as a testimony to minds mired in conflicted allegiances between this world and 'the Beyond'. An attentive reader cannot miss it that this selection by Hägglund is historically reduced to religious thought that had been dressed in metaphysical garb. It is obvious that Augustine's Christianity was immersed in the heritage of Platonism, epistemologically preferring 'the eyes of mind' over the bodily senses. In his intellectual vision, Augustine perceives God as an immutable, luminous Being, whilst Augustine sees himself as 'not yet Being' (Confessions VII:1). C.S. Lewis' theology is also indebted to Platonism: Narnia is an imaginary version of the real, eternal Narnia; so is this world in relation to heaven (Clark 2007:128-129).

\section{Pitting some theological voices against Hägglund's criticism of belief in immortality: Emmanuel Falque, Ebenhard Jüngel and Dewi Zephaniah Phillips}

Hägglund's view of religion would have been more nuanced and less biased, had he taken cognisance also of contemporary post-metaphysical trends in theology. He should certainly

4.cf. Taylor (2007:264-265): "There is another way of putting my point about the relation between Reform and what we today call "secularization", starting from this last term itself. Its root is in saeculum', the Latin word for a big tract of time, an age. The Greek term it often translates is 'aion' (English 'aeon'). More recently, the term in modern languages (siècle, siglo) comes to a fixed quantity, of 100 years, what in English we call a century. Now 'saeculum' and the adjective 'secular' come to be used in Latin Christen - a secular agedom as one term in a contrast, in fact several used in Latin Christen - a secular agedom as one term in a contrast, in fact several related contrasts. As a description of time, it comes to mean ordinary time, the time which is measured in ages, over against higher time, God's time, or eternity. And so it can also mean the condition of living in this ordinary time, which in some respects differs radically from those in eternity, the conditions we will be in when we are fully gathered in God's time. Two obvious features of our condition here, which are no part of God's ultimate plan for us, are that we live in states, that is, under political power, and that we live under régimes of property, and there are many others. 
have trodden more carefully in his treatment of the eschata, the last things of humanity, which bring bouts of vertigo even upon the most experienced of theologians. For example, Hägglund could have found at least partially acceptable the most recent phenomenological approach of for instance the French Catholic theologian Emmanuel Falque. In his Metamorphosis of Finitude: An Essay on Birth and Resurrection, Falque (2012) insists that Heidegger's existential analytics concerns both the 'believer' and the 'non-believer' in the same way. Like the philosopher, the theologian must take finitude as the first given. Philosophy is fundamentally atheist in delineating the strictly finite modalities of Dasein, according to Falque. Even the believers must consciously situate themselves in such a position and accept the impassable immanence of their lives without any certainty of opening up to transcendence (Falque 2012:13-15). 'The avowal of a finite temporality is opposed to its impossible derivation from eternity of some kind, and the recognition of the possible depth of humanity without God' (Falque 2012:15). In this way, religious persons take up the burden of their humanity alongside their fellow human beings, who try to live their lives authentically without God. We cannot consent any longer to claims that human beings possess the perception of infinite before the finite (Falque 2012:27).

Falque namely takes to task the prevalent derogatory view of atheism in modern Catholic theology as a 'drama' or a 'kind of deviation' (Falque 2012:34-35). In his opinion, we should interpret atheism more as an existential attitude than as a theoretical certitude. Falque even makes a case for a default layer of 'grammar' that Christians could share with their non-believing contemporaries, making New Atheism more comprehensible in this way. Following Ludwig Feuerbach, Christians should recognise the illegitimacy of the automatic fusion of love and faith in God. One does not require faith in God to experience or share love. This is the point of departure for acknowledging the legitimacy of ethics and philosophies of life outside of the framework of the Christian narrative.

In addition to having their share in the default grammar of impassable immanence, Christians are nonetheless attentive to the kerygma of resurrection, which Falque refers to as the 'metamorphosis' of the structure of world and time. He had chosen this metaphor intentionally. Resurrection is, to wit, not a guarantee of some continuation of finitude. It does not bring things to a conclusion or restore them as they had been before. Resurrection is supposed to transform matters - a process that stands central in human spirituality (Waaijman 2002:455-483). Moreover, we should not think of resurrection as an event to which God is an external agent, providing little or no reason for this metamorphosis. Resurrection is not principally an affair for human beings, although it concerns them too. Following the tradition of the Church Fathers, Falque grasps this transformation as an intra-divine event: in the Son's death, which is in all respects human and ordinary, the weight of finitude is passed to the Father and transformed (Falque 2012:43-44).
However, we must admit that the idea of eternal life as commonly perceived by believers may well in some ways be deficient, as insinuated by Hägglund. This deficiency is probably seated in the very notion of completeness associated with it, bringing the unique and unrepeatable ecstatic flow of the temporality of human life to a standstill. Eberhard Jüngel's treatment of the subject of death and resurrection can provide us with partial clues to forging such an understanding. In his book Tod $(1993)^{5}$ that despite its initial publication in the early 1970s still bears clear relevance for contemporary readers, Jüngel does not fail to emphasise time as the formal ontological structure that translates itself into the historicity (Geschichtlichkeit) and temporality (Zeitlichkeit) of human life. Thanks to the temporal ecstasies of the past, present and future, human beings can have their lifetimes as history and as interpersonal communication (Jüngel 1993:148-149). For Jüngel, death is an anthropological passivity that human beings have to suffer in their passing away, which renders them entirely relationless. Death disrupts one's bond to the caring mode of being and the ongoing openness to the world. Not unlike Falque, Jüngel too makes clear that Jesus' resurrection cannot be understood as a reversal of the events of Good Friday (Webster 1991:88-90). The day on which Jesus died and Easter Sunday do not represent two distinct mysteries, but rather two sides of one mystery: the identification of God with the dead man Jesus. Whilst in death all relations wane away, God interposes himself to defy the relationlessness of death. This victory, however, does not imply that our share in Jesus' resurrection entails lifting us out of the finitude and setting us on a path of endless continuity. The resurrection of Jesus was not an event following the events of Good Friday, opening a new chapter in his biography. Jüngel thus does not hold out on criticism of eternal life interpreted as ongoing continuity.

In Jüngel's view, this model suits well the goals of an eschatology catering to religious beliefs and expectations that aim at personal self-preservation after death. Jüngel envisions human life to be eternal only as a finished and integrated whole, embraced by God. It is a person's lifetime as the completed past that enters God as its Beyond, and is glorified as such (Jüngel 1993:152-154). Yet, according to Heidegger, it is the future that should be viewed as the most authentic phenomenon of human life in its temporality. Dasein is constantly ahead-of-itself (Heidegger 1962:378). Whilst reflecting on Jüngel's eschatology, one cannot escape the feeling that in spite of the glorification of one's lifetime in God, something is irrevocably lost in eternity, namely the interplay of temporal ecstasies that represent the very essence of our finite lives. Human beings suffer death, or as Paul writes: 'Our earthly tent we live in is taken down' (2 Cor 5:1); yet according to Jüngel, we can actively engage death during our lifetime: humans are semiotic beings inhabiting different systems of language and linguistic structures. For Jüngel, this is an important property, because he insists on putting across the most authentic Christian language about death and eternal life (Webster 1991:90).

5.For an English traslation of this book, see Jüngel (1975) 
Nevertheless, in our capacity as languaged beings we can still turn towards other narratives, attempting to come to terms authentically with our mortality, including that as expressed within secular humanism.

We can engage Hägglund's position from yet another and probably the most viable perspective. Dewi Zephaniah Phillips might not have ranked with the most promintent religious thinkers of the second half of the 20th century, ${ }^{6}$ but his books influenced by the philosophy of Ludwig Wittgenstein offer an interesting perspective on a range of religious issues, including belief in immortality. In his study entitled Death and Immortality, which was published in 1970, Phillips provides a persuasive apologia of this belief. Whilst critically engaging philosophical attitudes seeking to prove belief in immortality as logically inconsistent and empirically non-verifiable, Phillips takes up a behavioural stance to vindicate the expectation of life beyond the grave. In his opinion, inquiring whether belief in immortality rests on a mistake is itself a fallacious undertaking. Even those theologians and philosophers of religion who personally subscribe to belief in immortality and refute their critics on this point by striving to prove the factual truth of this belief are committing what Phillips calls 'a logically unique expectation' and are hence mistaken (Phillips 1970:61). Many scholars, regardless of their position on belief in immortality, often overlook the fact that this belief is bound up with a network of various attitudes towards the world. Viewing the body as the prison of the soul is one of them.

Phillips himself is convinced that the issue of the relation between believers and the accounts they give of their beliefs cannot be reduced to the question of whether we can be raised from the dead as a substantiated expectation. In a way, the debate on proving or disproving belief in immortality amounts to uprooting religious convictions from the context of ordinary language situations. Ludwig Wittgenstein claims that the word 'God' is amongst the earliest we learn in our daily communication. It is communicated to us through pictures or catechisms, but not with the same consequences like the pictures of ants (Wittgenstein 1966:59). Talking of God and ants belong to two different language games, which also lead to different actions. Wittgenstein claims that the knowledge of God is communicated through 'pictures'. A 'picture', or in a more general way 'a world picture', takes up an important place in Wittgenstein's philosophy. It accounts for various domains of the knowledge accumulated by a community, be it accounts of the origin of the world, the various physical processes taking place in the world, the role of sexes and reproduction, medical expertise and finally also religious beliefs. A world picture must not be necessarily a theory of the world. What probably matters more in our debate is that such a picture guides the behaviour of those who hold fast to it. Inquiries and assertions made within a community are not Von Sass (2010). all equally subject to testing (Kober 1996:417-420). In this respect, we can undoubtedly make more 'tested' assertions about for instance ants than about God.

Cherishing this view, Wittgenstein in effect protects religious beliefs. Thinkers who insist on the logical consistency and on the empirical veracity of a religious belief commit a mistake. Phillips follows the fold of arguing that instead of embarking on such an investigation, we should rather concentrate on the communicative contexts in which religious beliefs are employed. Religious beliefs are namely dressed in the language of myth. A myth is not necessarily a prediction that certain things are going to happen, but rather an embodiment of or reflection on the meaning of life and death. To support his argument, Phillips makes another reference to Ludwig Wittgenstein, to his notes on James Frazer's Golden Bough. Wittgenstein speaks here about the impressiveness the rites of ancient people may have upon us. He refers in particular to the story of the forest-king of Nemi and Diana in ancient Italy. James Frazer recounts the story in a tone stressing that we witness something horrible happening there. The answer why this is happening rests on the very proceedings of the rite that strikes us not only as impressive, but at the same time also as horrible and tragic. When we place the story of the forest-king side by side with the expression 'the majesty death', they are one. It was because of this majesty that the rite had to be terrible (Frazer 2009:12-30; Wittgenstein 1967:235-236).

Phillips applies these observations to religious beliefs like the Last Judgement, to the reunion after death in Heaven and to God's omniscience and providence. What we find impressive about those beliefs is what produces them. Phillips puts his point across as follows: 'Believing has little in common with any kind of conjecture ... It has to do with living by them [beliefs], being afraid of them' (Phillips 1970:68). Again according to Wittgenstein, as Phillips emphasises, religious convictions assume a place of unshatterable beliefs that create a framework for those who live by them to assess themselves and the events they encounter in their lives (Phillips 1970:69). We can imagine the members of our families, most of whom have already passed away, embracing each other in a reunion after death. Somebody else can obviously ask questions about the details of the 'facticity' of this reunion. These are, however, unsuitable questions, according to Phillips. It is worth to note also that Paul Ricouer does not judge such inquiries harshly, arguing that symbols and myths display a tendency to transform into speculatively elaborated, detailed and rationalised doctrines, as it was the case with the articulation of the teaching of original sin in Late Antiquity (Gregor 2019:46-53; Ricouer 1967:3-10). The rational-critical approach undoubtedly also allows space for the agenda of contemporary theology and philosophy of religion involved in the unprejudiced and well-balanced study of the 'essence' of religious beliefs, and not only of their functioning in the lives of believers. It is however predominantly the latter that Phillips has in mind: the very picture of a family reunion may play a crucial religious and 
ethical role in our lives. Believing that our relationship may continue beyond the grave, we take upon ourselves the commitment to the living as well as the dead as something that even death cannot destroy. Phillips' (1970) very words underline this:

$[T]$ he picture of the family reunion after death is not a prediction for which he [the believer] has evidence, but a vision in terms of which much of his own life is lived out. (p. 68)

In the same breath, Phillips makes clear though, these pictures (beliefs) are not just figures of speech we can do away with or replace them with other ways of saying. Religious pictures will prove stronger and more expressive in the language practices of a community. Yet, on the other hand, we should beware of regarding religious language and its power as an unshakeable given. Almost at all times and all places, there have been sceptics who were familiar with the religious language game played in their culture. However, these questioners refused to play along. Therefore, nobody can deny that religious beliefs can lose their hold on people's lives. They may suddenly become incoherent, not only for a limited number of individuals but also for a large swath of the population.

Phillips' uptake on losing one's faith is thus also behavioural. The new (secular) picture supplanting the old (religious) one takes up a rival position not because of its claim that the original picture is a mistake, but because of its operativeness in a person's life. The person's attention is now focussed on the new picture and their energies are spent in that direction (Phillips 1970:74). In such a case, we stop to respond to certain circumstances of our life in the way demanded by religious language practice. ${ }^{7}$ Belief in immortality, for example, ceases to exert its power in a person's life, turning into a bundle of unintelligible assertions.

It ought to be noted that such a shift does not relate solely to the destiny of religious beliefs. Phillips demonstrates this on the decline in belief in the honour of a family in middle class society of New York of the 1870s, as described by Edith Wharton in her novel The Age of Innocence. For the next generations, this notion became difficult to comprehend and to live by (Phillips 1970:74). Phillips' analysis agrees with the observations referred to above, made by Cupitt on the gradual process of the transformation of religious language practices in the United Kingdom, in which God-idioms have been replaced by Life-idioms amongst people estranged from the established churchly language.

Phillips thus provides us with strong arguments to deal critically with some of Hägglund's assertions. Firstly, Phillips shows us the futility of disproving belief in immortality by questioning its logical coherence. This is undoubtedly the case with Hägglund's criticism of the notion of eternal life, understood either as timelessness or as an endless continuum. Hägglund argues against belief in eternal life with a view to prove the lack of its coherence and intelligibility. Secondly, Phillips has shown that religious language is essentially thisworldly. Its main purpose is to guide our actions in the physical and social environment of which we are a part. This is also true with regard to belief in resurrection and eternal life. Such a belief powers and stimulates believers' attitudes to themselves and the world by sustaining and fostering care amongst the living for one another. This social bond is sealed by belief in the consummation of such care in eternity. Thirdly, Hägglund argues that our care and commitments are meaningful only in relation to the present and future. We can only care for and be committed to those who live their finite lives with us. This assumption implies that our commitment to those who have already passed away is close to futile.

In the introduction to his book, Hägglund for instance conjures up a picture of the landscape of Sweden on the shores of the Baltic Sea, the place where his ancestors lived for centuries and where Hägglund used to spend every summer earlier in his life. He describes this landscape as dramatic: ragged mountains and tall cliff formations created during the descent of the ice 12000 years ago. Hägglund feels connected with this geological history as well as with the history there of his family, which reaches back to the 16th century. Yet, the reader can sense that Hägglund's enthrallment for the past has its limits. In the end, this manifold history is presented by Hägglund as a precondition for his own finite existence that is oriented towards a future that is not given (Hägglund 2019:6-7). As Hägglund further into the book takes Augustine's, Luther's and C.S. Lewis' grieving as examples and insinuates that encountering deceased people in our memories and reliving our experiences with them are essentially traumatising. Therefore, the past seems beyond the scope of interest for Hägglund, as he quotes from Lewis' A Grief Observed the following lines: ' $\mathrm{H}$. is dead. It is to say: All is gone. It is a part of the past. And the past is the past and that is what time means ...' (Hägglund 2019:65; Lewis 2001:25).

Dealing with the past, in particular in a religious way, is therefore tantamount to disowning our lives here and now. With all due respect, Hägglund's anthropology is impoverished in this respect, as it puts the past aside, concentrating only on the living and on those who may come after us. This lacks the proper connection of all the three ecstasies (vide supra) of our lives.

Phillips has in effect shown in his book on death and immortality that religious language is more encompassing and rounded off in this respect, uniting the past with the present and future. We can care for and continue to be committed even to those who have passed away and are not amongst us any more. Christianity reunites the past, present and future, in particular in the belief in the communio sanctorum as one of the last articles in the Apostles' Creed. The communion of saints, the living and the dead, is essentially an eschatological theologumenon. This communion enters into death with Christ, rises from death in Christ and gives glory to God in Christ. 
Some church historians are convinced that the articulation of this article as part of the Apostles' Creed arose from devotions to the blessed dead, which thrived in the regions where the Apostle's Creed developed, in particular amongst Gallic Christians. These believers practised a fellowship with the martyrs they had known in their time, or with the memory or testimony of those who were offered them on behalf of the community of the living. These martyrs represented the power of the Christian faith spoken unto death, and the affirmation of all the validity of all the promises given in Christ. The dead stood as a 'living' testimony to that belief (Delorenzo 2017:10-11).

Such a commitment to the dead is embedded even more strongly in traditional African spirituality, according to which the power of life is passed on through the relationship between ancestors and their descendants. Ancestors exert immense authority and power on their posterity. The relation of the living to the deceased is so strong that the dead are actually viewed as 'living-dead' to the point that even as the dead they are in danger of 'dying'. The ancestors may pass for instance away again if they are not properly remembered and acknowledged as superior by their living descendants. These ancestors finally lose their existential relevance when those who knew them on their part die, and the ancestors' particular identity is then dissolved into the general category of 'our ancestors'. The 'living-dead' can also be excommunicated from the community of the living if they are deemed to pose a threat to the prosperity of this community (Nürnberger 2007:26-27; cf. Gehmann 1999). The coordination of these views of death and life on faith is remarkable and clear to observe.

\section{Conclusion}

To summarise, Hägglund's book is certainly not immune to shortcomings and anachronisms, in particular as to the onesided way the word 'secular' is employed in it. Its main shortcoming, though, presents itself in the less than an indepth engagement with religion. It seems as though the arguments laid out in Hägglund's book have been tailored purposefully to present a kind of a manifesto of secular humanism, which runs alongside Hägglund's political views.

On the other hand, whilst engaging Hägglund's main arguments in this last paragraph of our article, it is clear that some of Hägglund's points may be interpreted as consistent with contemporary theology and religious philosophy informed by the Heideggerian heritage. Critical and nonfundamentalist theology cannot get away from having its stake along with atheism in the default grammar of finitude, even though theology may part ways with atheism in looking towards the horizon of the dissolution and transformation of this grammar into the grammar of resurrection. In spite of this difference, alternative contemporary spiritualities oriented to the impassable immanence of finitude are not necessarily foes of critical theology. To the contrary, such spiritualities may be allies in pushing through a responsible action addressing the accumulating political, social, economic and environmental problems of our new decade, the 2020s.

Amidst a Covid-19 pandemic, the latter bears down heavily on humanity in all parts of the world. Irrespective of our ethnic, cultural or political backgrounds, we can see healthcare workers around the world standing shoulder to shoulder with other key professionals, to save lives, regardless of the nature of their personal beliefs.

\section{Acknowledgements Competing interests}

The authors declare that they have no financial or personal relationships that may have inappropriately influenced them in writing this research article.

\section{Authors' contributions}

D.B. was the conceptual leader with this contribution, with C.L. adding the postsecular framework.

\section{Ethical considerations}

This article followed all ethical standards for research without direct contact with human or animal subjects.

\section{Funding information}

This research received no specific grant from any funding agency in the public, commercial or not-for-profit sectors.

\section{Data availability}

Data sharing is not applicable to this article as no new data were created or analysed in this study.

\section{Disclaimer}

The views and opinions expressed in this article are those of the authors and do not necessarily reflect the official policy or position of any affiliated agency of the authors.

\section{References}

Augustine, 1972, St. Augustine's confessions with an English translation by William Watts, The MacMillan, New York, NY.

Augustine, 2003, On the Trinity (Books 8-15), Cambridge University Press, Cambridge.

Beckford, J.A., 2012, 'SSSR presidential address public religions and the postsecular: Critical reflections', Journal for the Scientific Study of Religion 51(1), 1-19. https:// doi.org/10.1111/j.1468-5906.2011.01625.x

Benson, I.T., 2011, 'South African Charter of Religious Rights and Freedoms', International Journal for Religious Freedom 4(1), 125-134.

Benson, I.T., 2012, Living together with disagreement, Pluralism, the secular, and the fair treatment of beliefs in law today, Connor Court Publishing, Ballan.

Benson, I.T. \& Lombaard, C., 2019, 'The South African Charter of Religious Rights and Freedoms: A review and evaluation of its composition and of its reception in news media', Law, Media Studies and Theology public seminar, University of South Africa, Pretoria, South Africa, February 01, 2019.

Biernot, D. \& Lombaard, C., 2017, 'Religious experience in the current theological discussion and in the church pew', HTS Teologiese Studies / Theological Studies 73(3), 1-12. https://doi.org/10.4102/hts.v73i3.4347

Bloomendaal, P.F., 2006, A critical evaluaiton of D.Z. Phillips' Philosophy of Religion, Peeters, Leuven. 
Brown, A., 2018, 'The NHS's new humanist chaplain is a welcome sign of our shifting spirituality', The Guardian, viewed 30 April 2020, from https://www.theguardian. sprituality', The Guardian, viewed 30 April 2020, from https://www.thegu

Burkeman, O., 2019, 'This life and outgrowing God review - Heaven, atheism and what gives life meaning', The Guardian, viewed 03 August 2020, from https:// www.theguardian.com/books/2019/oct/02/this-life-martin-hagglundwWw.theguardian.com/books/2019/or

Clark, D.G., 2007, C.S. Lewis: A guide to the theology, Blackwell Publishing, Malden, MA.

Cupitt, D., 2012, The last testament, SCM Press, London.

Dawkins, R., 2006, God delusion, Bantam Press, London.

Delorenzo, L.J., 2017, Work of love: A theological reconstruction of the communion of Saints, University of Notre Dame, Notre Dame.

Dennett, D., 2006, Breaking the spell: Religion as natural phenomenon, Penguin Group, New York, NY.

Diez, G., 2019, 'Greta Thungerg "How Dare You": Angst and Endlichkeit', TAZ, viewed 03 August 2020, from https://taz.de/Greta-Thunbergs-How-dare-you/!5627066/.

Engelke, M., 2014, 'Christianity and the anthropology of secular humanism', Current Anthropology 55(S10), S292-S301. https://doi.org/10.1086/677738

Evans, C., 2017, The social Gospel in American religion: A history, New York University Press, New York, NY.

Falque, E., 2012, The Metamorphosis of finitude: An essay on birth and resurrection, Fordham University Press, New York, NY.

Frazer, J.G., 2009, The golden bough: The study of magic and religion, The Floating Press, Auckland.

Gehmann, R.J., 1999, Who are the living-dead?: A theology of death, life after death, and the living-dead, Evangel Publishing House, Nairobi.

Gregor, B., 2019, Ricouer's Hermeneutics of religion: Rebirth of the capable self, Lexington Books, Lagham.

Hägglund, M., 2008, Radical atheism: Derrida and the time of life, Standford University Press, Standford, CA.

Hägglund, M., 2012, Dying for time: Proust, Woolf, Nabokov, Harvard University Press, Cambridge, MA.

Hägglund, M., 2019, This life-why mortality makes us free, Profile Books, London.

Harris, S., 2014, Waking up: A guide to spirituality without religion, Simon \& Schuster, New York, NY.

Heidegger, M., 1962, Being and time, Maxwell, Oxford.

Hitchens, C., 2007, God is not great: How religion poisoned everything, Atlantic Books, London.

Hoffmann, P., 1993, 'Death, time and history: Division II of being and time', in C. Guignon (ed.), The Cambridge companion to Heidegger, pp. 195-214, Cambridge University Press, Cambridge.

Humanists UK., 2019, About us, viewed 03 August 2020, from https://humanism.org. uk/about/.

Jüngel, E., 1975, Death: The riddle and the mystery, Westminster John Knox Press, Louisville, KY.

Jüngel, E., 1993, Tod, Gütersloher Verlagshaus, Gütersloh.

Karp, P., 2019, 'Religious discrimination bill, what will Australians be allowed to say and do if it passes?', The Guardian, viewed 30 April 2020, from https://www. theguardian.com/world/2019/dec/14/religious-discrimination-bill-what-willaustralians-be-allowed-to-say-and-do-if-it-passes.

Kenneth, D.G., 2016, 'Missed appropriations: Uncovering Heidegger's debt to Kierkegaard in being and time', PhD thesis, University of Denver.

Kober, M., 1996, 'Certainties of a world-picture: The epistemological investigation on certainty', in D. Sluga \& D.G. Stern (eds.), The Cambridge Companion to Wittgenstein, pp. 411-448, Cambridge University Press, Cambridge.

Kourie, C., 2009, 'Spirituality and the University', Verbum et Ecclesia 30(1), 148-173. https://doi.org/10.4102/ve.v30i1.67
Leaves, N., 2005, Surfing on the sea of faith: The ethics and religion of Don Cupitt, Polebridge, Santa Rosa, CA.

Leaves, N., 2011, Religion under attack: Getting theology right, Polebridge Press, Salem, OR.

Lewis, C.S., 2001, A grief observed, Harper \& Row, New York, NY.

Lombaard, C., 2018, 'Spiritualityd ... Spirituality in our time - In conversation with Hartmut Rosa's theory on social acceleration', HTS Teologiese Studies / Theologica Studies 74(3), 1-7. https://doi.org/10.4102/hts.v74i3.5051

Mills, J., 2016, Inventing God: Psychology of belief and the rise of secular spirituality, Routledge, London.

Molendjik, A.J., Beamont, J. \& Jedan, C. (eds.), 2012, Exploring the postsecular: The religious, the political and the urban, Brill, Leiden.

Muller, P. (ed.), 2002, Die Nuwe Hervorming, Protea Boekhuis, Pretoria.

Nürnberger, K., 2007, The living dead and the living God: Christ and ancestors in the changing Africa, CW Powell Bible Centre, Pretoria.

Nynäs, P., Lassanda, M. \& Utrianen, T. (eds.), 2012, Postsecular society, Transaction Publisher, New Brunswick, NJ.

Okeja, U., 2019, Religion in the era of postsecularism, Routledge, London.

Pelosi, I.A., 2018, 'Outside the Bubble: On the Road w/ Alexandra Pelosi (2018) | Official Trailer | $\mathrm{HBO}^{\prime}$ ' YouTube, viewed 30 April 2020, from https://www. youtube.com/watch?v=FP8pFWZ-vPE.

Phillips, D.Z., 1970, Death and immortality, MacMillan and Co Ltd, London.

Phillips, D.Z., 1986, Belief, change and forms of life, MacMillan and Co Ltd, London.

Rashid, T., 2020, 'The curious religiosity of Martin Hägglund's postsecularism', Prospect, viewed 03 August 2020, from https://www.prospectmagazine.co.uk/ magazine/this-life-why-mortality-makes-us-free-martin-hagglund-reviewsecular-faith-spirtuality.

Ricouer, P., 1967, The symbolism of evil, Beacon Press, Boston, MA.

Rousseau, J., 2012, 'Staring into the abyss of "special privileges"', Daily Maverick, viewed 31 January 2019, from www. dailymaverick.co.za/opinionista/2012-02-05staring-into-the-abyss-of-special-privileges.

South African Charter of Religious Rights and Freedoms, 2009, South African Charter of Religious Rights and Freedoms, viewed 15 October 2020, from https://www.fsi. org.za/uploads/2010/11/CharterInnerFinal2.pdf.

Stern, M., 2019, 'The Trump justice department has turned religious liberty into a licence to discriminate', USA Today, viewed 03 August 2020, from https://eu. usatoday.com/story/opinion/2019/06/25/trump-gives-religious-conservativesusatoday.com/story/opinion/2019/06/25/trump
license-to-discriminate-column/1540435001/.

Taylor, C., 2007, A secular age, Harvard University Press, Cambridge, MA.

Vanhoutte, K., 2020, The revenge of the words, On language's historical and autonomous being and its effects on "secularisation"', HTS Teologiese Studies / Theological Studies 76(2), a6076. https://doi.org/10.4102/hts.v76i2.6076

Van Huysteen, W., 2006, Alone in the world? Human uniqueness in science and theology, William B. Eerdmans, Grand Rapids, MI.

Von Sass, H., 2010, Sprachspiele des Glaubens: Eine Studie zur kontemplativen Religiounsphilosophie von Dewi Z. Phillips mit ständiger Rücksicht auf Ludwig Wittgenstein, Mohr Siebeck, Tübingen.

Waaijman, K., 2002, Spirituality: Forms, foundations, methods, Peeters, Dudley, MA.

Webster, J.B., 1991, Eberhard Jüngel: An introduction to his theology, Cambridge University Press, Cambridge.

Wittgenstein, L., 1967, 'Bemerkungen über Frazers: The golden bough', Synthese 17(1), 233-253. https://doi.org/10.1007/BF00485029

Wittgenstein, L. \& Barrett, C. (eds.), 1966, Lectures and conversation on aestetics, psychology and religious belief, Blackwell, Oxford.

Zeidan, D., 2003, The resurgence of religion: A comparative study of selected themes in Christian and Islamic discourses, Brill, Leiden.

Zuckermann, P., 2014, Living the secular life, Penguin Books, New York, NY. 